\title{
Governmentality, the Discourse, and Indonesia's Family Planning Program
}

\author{
Mohamad Dziqie Aulia Al Farauqi ${ }^{1}$, M. Najeri Al Syahrin ${ }^{2}$ \\ \{mdaa343@umkt.ac.id $\left.{ }^{1}\right\}$ \\ International Relations Department, Universitas Muhammadiyah Kalimantan Timur, 75243, \\ Indonesia ${ }^{1}$ \\ Politics Department, Universitas Lambung Mangkurat, 70124, Indonesia²
}

\begin{abstract}
This paper aims to analyze how Foucauldian perspective sees the discourse of a happy-prosperous-small family and the Family Planning Program in Indonesia. Those are integrated state programs of Indonesia government since 1970 to control the population. By using the concept of governmentality, Foucault saw this as a method to discipline the live over society using the regulation, discourse making, state apparatus and method to establish a very nurture circumstance for the economic stability in Indonesia. This paper argues that the process of governmentality, the Family Planning program, and discourse making of a happy prosperous small family are intertwined in to control population. This paper sheds light on the problematization of how they are produced, on what discourse they go and what kind of subjectification they used in the implementation of Family Planning program Indonesia.
\end{abstract}

Keywords: Governmentality, Prosperous Small Family, Population, Discourse, Family Planning Program, Foucauldian

\section{Introduction}

Overpopulation is one's of Indonesia's current major issues. According to the UN, the population of Indonesia in 2015 reaches about 257.56 million people, or about 3.50 percent of the total population of the world [1]. Furthermore, according to BPS Indonesia Population Projections 2010-2035, the population of Indonesia within the last 5 years had been increasing. In 2011, the population of Indonesia reached 241.99 million people and continued to increase to 255.46 million people in 2015 . It contributed hugely to the increasing world's population in the next recent years because the world population envisaged reaching 8.5 billion people in 2030, increase to 9.7 billion in 2050 and there is no signal of this figure will be declining [2].

Most of Indonesia's population growth concentrated in urban areas. A significant increase in population, especially among the urban poor, would compound some of the problems. In Indonesia, population problems also felt by the people amongst those suffering in a low quality of life and the amidst of national food shortage. ironically, this abundance of people not supported by the quality of life and adequate food availability. Thirty per cent of households stated that their food consumption was less than their needs. More than a quarter of children under five years have less than the ideal weight. Even before the crisis in Indonesia in 1997 and 1998, $42 \%$ of children under five years old suffered from stunting, due to malnutrition [3]. And now, even though Indonesia's rice consumption per capita is high, it still relies on rice imports from Vietnam and Thailand [4]. 
Despite the increase, Indonesia had done the attempt to reduce population since 1970 by the establishment of the Family Planning program or Keluarga Berencana (KB) Program. It is an effort to regulate the number of births in such a way that the birth does not cause more harm than good for the parents, community and society in general. This attempt includes the usage of various types of contraception tools to prevent pregnancy, the education to increase the knowledge and awareness of family through maturing the age of marriage, birth control, fostering family resilience, and the empowerment to have a less-child family program [5], [6]. Thereof, The Family Planning Program also aims to improve people's living conditions by reducing birth rates so that population growth in Indonesia does not exceed production capacity [7].

The Family Planning Program is a vital population control effort, in reconstructing society to separate its personal life (reproductive problems) into social issues (overpopulation). This paper argues that the implementation of the family planning programs is the effort of Indonesia's government to discipline the society under the discourse of a norm of happy, prosperous small family. By using foucault's concept of governmentality, this research will shed light on the rationality, making of discourse, problematization, discourses, and mode of subjectification of governmentality of this operation in everyday life in indonesia. This research will use literature research and a depth purposive interview of the stakeholders and the objects of policies.

\section{Literature Review}

Governmentality is the concept proposed by Michael Foucault. It is a mechanism of how the government has power over the body of society. Because the state has sovereignty to control the population in order to help the country solve the country's problems. Population, on the other hand, is the object that is subjectivity in helping the country's problems. To make them as Subject, Communities need to be given an understanding of the various things they can do and what they cannot do for the country through a series of strategies, law enforcement, policy interventions with the aim that they can become subjects and adjust so they can help the country well. It can be interpreted as a programmed state effort to lead the subject (society), whether done by structuring the subject field by creating a state that can make the subject develop or influence the development of the subject itself. The limitations of governmentality revolve around problems and techniques for governing in the political context to create an order that can support the preservation of economic governance. All of this was achieved to help the government achieve its economic goals which were its main mode. In this context government intervention becomes as a tool to make the power of state over the maximum economy achievable [8].

In governmentality, government sought ways to regulate the conduct of the inhabitants of a territory, but to do this through ruling 'from a distance'. Governmentality refers to the ways in which a state attempts to regulate its people and territories [9]. Governmentality concerned with the 'art of government': with 'knowledges of how to rule but also with . . . the organized practices through which we are governed and through which we govern ourselves' [10]. Burchell [11] argues that governmentality has two aspects: the technical aspect or 'the will to govern' reflected in the principles and goals that guide peoples' behaviour and manifested in the practices that regulate behaviour and knowledges about 'the reasons, justifications, means and ends of rule' [12]. Miller and Rose [13] describe this as the mentality of rule. For Rose [14], it has a moral aspect in that it is concerned with the allocation of responsibility for the tasks of 
governance, but also an epistemological aspect in that these ideas 'embody particular conceptions of the objects to be governed'. For Foucault [15], the focus of governance from the nineteenth century has been upon the protection of the population through the materiality of power operating on the very bodies of individuals. The dominant model of governance or governmental rationality operating from this time in Western countries has been liberalism which in line with democracy. The central discovery of democracy for Foucault was that it was not possible to govern too much. He states, it seems to me that, at that very moment it became apparent that if one governed too much one did not govern at all - that one provoked results contrary to those one desired. By this we can elaborate more that Indonesia is one amongst state that adopt democracy in its government.

\section{Method}

There are several aspects that must be applied in examining the concept of governmentality. According to greenhalgh [16], governmentality has a focus on knowledge, problematization, strategic aims, governmental techniques and modes of subjectification (intended and unintended) effects. According to rabinow and rose [17], there are at least three things that must exist in explaining public policy using the concept of governmentality, namely truth discourse, strategies of intervention, and mode of subjectivation. On the other hand, according to legg [18] in the context of the implementation of foucault's theory in geographies explains that there are at least five aspects that must be discussed such as subjectification, information collection and theoryorialization, geopolitical imagination, state technology and international comparison [18]. Rabinow and rose [17] said that the course of biopolitics and governmentality at least must include these three: discourse, strategic of intervention and modes of subjectification. This paper will discuss at least three aspects that need to be present, namely problematization, discourses, mode of subjectivation.

\section{Results and Discussion}

\subsection{Problematization: the birth of the birth control programs in Indonesia}

The excessive population growth has been one concerning indonesia's government since 1970. The program of controlling population growth was one of five aspects in the Rencana Pembangunan Lima Tahun (REPELITA 1) Five-year Development Plan I of Soeharto Regime in 1969-1964. Indonesia in the 1970s experienced unprecedented health problems. The situation and health problems that happened at that time in Indonesia were very alarming. The spread of disease (Smallpox, Tuberculosis, Malaria, Colera, PES, and Frambosia) is very high. The spread of this disease occurs in various regions in Indonesia and infected many communities. For example, Tuberculosis, this disease affects about $4 \%$ of the entire population of Indonesia [19].

This condition is worsened by inadequate Hygiene and Sanitation and health facilities. Even hospitals in Indonesia cannot keep up with the increase in population that occurs. According to history, that in 1959-1965 Comparison of beds in hospitals with a population of 8: 1000 residents. Not to mention coupled with the lack of capacity and availability of health equipment that is damaged and lacking in maintenance. Problems also occur in the availability of medical personnel in Indonesia. In 1968 Indonesia had 5,000 medical personnel with a population of 
115 million people, so that there was a ratio of doctors to a population of $1: 23,000$. This caused the maternal and infant mortality rates to be very high and this is certainly alarming and caused the life expectancy of the Indonesian population to be very small at only 48, 65 years in 1960 [19].

This problem is a result of the previous government's lack of attention on population issues. This is a problematization by the government to implement a family planning program and adopt a program that previously came from several community groups who are concerned with this condition and conduct education programs to the community related to the importance of thinking about self and family welfare by reducing the number of children in the family. They initiated the formation of the PKBI (Indonesian Family Planning Association) in 1957. PKBI also held a congress and urged the government to make the Family Planning Program a national program to solve this health problem. Finally, the New Order Government established the KB Program as part of REPELITA and formed the Family Planning Coordinating Board National (BKKBN) established on the basis of a presidential decree no.8 of 1970 [20]. The purpose of implementing the family planning program is to form a family small according to the socioeconomic strength of a family in a way arrangement for the birth of a child in order to obtain a happy family and prosperous who can meet their needs [21]. Finally, the Family Planning Program by the BKKBN, local government, health agencies and the community has become an annual national program of government until now. Although the population in Indonesia is still increasing every year, this program can educate the public through the Norms of a Happy and Prosperous Small Family (NKKBS) to help the government solve government problems related to population so that life expectancy in Indonesia is constantly increasing.

\subsection{The Discourse: A Norm of happy, prosperous small family and Family Planning Program}

Indonesia made A Norm of happy, prosperous small family as the goal of the implementation of the Family Planning Program by the Indonesian government to educate the public which was opposed by various religious groups from the community. Previously there was a discourse "many children have lots of good fortune" in the community. This discourse developed in Indonesian society, which is predominantly Muslim. This discourse originated from the influence of religious organizations in developing this discourse in Indonesian society and the pro-natalist vertical policy of the old order government.

The fertility policy adopted by the old-order government led by Sukarno, who led postindependence Indonesia from 1945 to 1965 , had a pronatal style meaning that the various policies produced relating to reproduction are policies that support birth. President Soekarno openly stated that he did not support the idea related to the Family Planning program launched by the PKKBI in the community, although he allowed the community to regulate birth spacing in order to maintain the health of mothers and children. He saw that the rapid population growth that occurred in Indonesia need to be resolved not by spreading discourse related to reducing the number of children but by the transmigration program. Transmigration is the movement of population from densely populated areas to less densely populated areas within national borders, in the context of national policies for the realization of a more balanced population distribution. the term transmigration itself was first put forward by Bung Karno in 1927 in the Indonesian daily Soeloeh. Then, in the Economic Conference in Kaliurang, Yogyakarta, along with the Economic Committee Committee on February 3, 1946. In addition, Vice President Muhammad Hatta mentioned the importance of transmigration to support the development of industrialization outside Java [22]. President Soekarno said in his speech commenting on the 
distribution of the Family Planning Program discourse as quoted by Isnaini [20] : "For me, the solution is to open more land, because if you open all the land in Indonesia, you can feed 250 million people, and I only have 103 million people ... In my country, the more children the better".

This pronatalist government is also supported by various Islamic religious institutions and organizations in Indonesia. Muhammadiyah and Nahdatul Ulama are two examples of Islamic organizations in Indonesia who reject the spread of this religion because it is contrary to religious norms related to fertility. In addition, the Indonesian Ulema Council (MUI) also rejected the spread because Islam considers that having many children is a noble thing and is recommended by religion. In addition, they assume that one of the goals of holding a marriage is to produce offspring, not limit it [20].

There was a rejection from the community regarding the implementation of the family planning program. This resistance has also been explained by Foucault that during periods of problematization, governments were forced to either adapt their programmes or launch justifications for what they were doing. people resisted, subverted and problematised these programmes, and were often aware of attempts to insidiously influence individual action. Such periods of reflexivity were not necessarily caused from without; tension between different governmental rationalities or techniques of power could also necessitate reform [22].

\subsection{Modes of Subjectification}

Modes of Subjectification is the term of government turns society as a object of politics into a subject of politics. According to Rabinow and Rose [18] Modes of subjectification, is the mechanism of which individuals are brought to work on themselves, under certain forms of authority, in relation truth discourses, by means of practices of the self, in the name of their own life or health, that of their family or some other collectivity, or indeed in the name of the life or health of the population as a whole.

The mode of subjectification can be done by the normalization that aims to objectify subjectivity. Because the power is discourse, government can classify and divide populations through establishing normative standards for bodily performance and presentation. This can normalize the body and discipline them. According to Foucault power is also operates through subjectification, which is concerned with the 'way a human being turns him or herself into a subject' [23]. Foucault argues for a process of self-formation that is mediated by exposure to discourse and incorporation of those knowledges into a concept of self, resulting in selfregulation in response to professional and scientific knowledges.

Normalization is an effort to make the population as a subject meaning that the population which is a political object needs to change their perspective to see the problems of government. They need to make themselves subjects too so that they can discipline themselves. Population growth is indeed a government problem, but population growth can also cause ourselves and family difficulties in the economic, health and social fields. In Indonesia, the government makes normalization with the discourse A Norm of happy, prosperous small family. The population is normalized to be able to achieve A Norm of happy, prosperous small family as a goal for a better family in the fields of economy, health, education. People need to realize that if they do not limit the number of their children. They will have difficulty living their lives [19].

Discourse A Norm of happy, prosperous small family is in article 11 paragraph 1 of Government Regulation of the Republic of Indonesia Number 87 of 2014 concerning Development of Population and Family Development, Family Planning, and Family Information Systems. "The Norms of Small, Happy, and Prosperous Families, here in after 
abbreviated as NKKBS, are values that are in accordance with religious and socio-cultural values that are entrenched in individuals, families, and communities, which are oriented towards a prosperous life with an ideal number of children to realize birth welfare and inner happiness."

People need to be aware that the family is their own responsibility. The government here has tried to change the mindset of the people that they have a great responsibility to manage their families. In this discourse the government has sought to popularize a sense of responsibility. As explained by Dr. Kartono Muhammad (chairman of PKBI) in his speech delivered at the Family Seminar welcoming the XXI century and its role in the development of Human Resources at Bogor Agricultural University in 1993. He considered that one of the main functions of A Norm of happy, prosperous small family was to popularize responsibility answer from the state to a smaller level, family, because families with more disabled children will have a greater chance of prosperity and happiness [24].

In Article 6 and 11 paragraph 3 of Government Regulation of the Republic of Indonesia Number 87 Year 2014 Regarding Development of Population and Family Development, Family Planning, and Family Information Systems, national family development policies are directed at: institutionalizing and civilizing NKKBS; empower family functions; independence of the family; empower local wisdom; improve the quality of the entire life cycle; meet the basic needs of the community; and empower community participation. So, the main function of the existence of the family planning program is to cultivate a norm of norm of happy, prosperous small family. While the specific function of this Family Planning Policy is in article 18. The program aims to; regulate the desired pregnancy, maintain health and reduce maternal, infant and child mortality; improve access and quality of information, education, counseling, and family services, planning and reproductive health, increase men's participation and participation in family planning practices; promoting infant breastfeeding and in an attempt to spart pregnancy intervals. In Article 18 above it is clear that there is an attempt by the government to regulate the community by making them aware of what their responsibilities are. It is hoped that with this program they can contribute to helping the government by participating in implementing family planning programs [19].

In addition, there is also a Surveillance function in the form of efforts to control the success of the family planning program by means of family data collection as cited in article 17. Family data collection is a procedure for collecting, processing, presenting, and utilizing demographic data, family planning data, family welfare data, and data on family members carried out by the Government and Regional Government together with the community simultaneously every 5 (five) years and the resulting data is accurate, valid, relevant, and can be accounted for [19].

\section{Conclusion}

This article tries to examine the implementation of family planning program as well as the establishment of the norm of the discourse of a norm of happy, prosperous small family using foucauldian perspective of governmentality in the democratic state such as indonesia. The governmentality studies analyse three aspects of problematization, discourses, mode of subjectification in the implementation of family planning program. This article found that using governmentality this program initially tried to solve health problems in Indonesia in the late of 1970 by converting population rationality of the discourse "many children have lots of good fortune" to a Norm of A happy prosperous small family. It had been one of the most concern Indonesia's government in the REPELITA I in 1970's under the regime of Soeharto to counter 
pro-natalist policy of the prior government of Soekarno. Later on, this program became the annual program of Indonesia government until now. Under the goal of a norm of happy, prosperous small family, the family planning program seeks more ambitious goal, namely the demographic bonus of Indonesia in 2030.

\section{Acknowledgement}

The acknowledgement of this study goes to; firstly, Kemenristekdikti for their supports financially, Secondly to LPPM UMKT for their effort administratively, and thirdly for BKKBN and Dinas Kesehatan Kota Samarinda for the time to discuss these issues.

\section{References}

[1] Riyadi, Et Al, Indikator Kesejahteraan Rakyat, Jakarta: Badan Pusat Statistik, 2015

[2] World Population Projected to Reach 9.7 billion by 2050, United Nations Report, July 29, 2015[Online], Available: Un.org, https://www.un.org/en/development/desa/news/population/2015report.html. [Accessed Desember 3, 2019]

[3] "Feeding Indonesia, Indonesia Policy Briefs - Ideas for the Future", World Bank, January 30 2005[Online], Available: http://siteresources.worldbank.org/INTINDONESIA/ Resources/Publication/280016-1106130305439/617331-1110769011447/8102961110769045002/Feeding.pdf [Accessed Desember 15. 2019]

[4] M.E Limenta. \& S. Chandra," Indonesian Food Security Policy”, Indonesia Law Review, Vol. 2, No. 1, pp. 245-265, 2017.

[5] H. Hartanto, Keluarga Berencana dan Kontrasepsi, Jakarta: Pustaka Sinar Harapan, 2004.

[6] D. Juliantoro, 30 Tahun Cukup: Keluarga Berencana dan Hak Konsumen, ed., Jakarta: Pustaka Sinar Harapan, 2000.

[7] Soekanto, Sosiologi Suatu Pengantar, Jakarta: P.T Raja Grafindo Persada, 2006.

[8] M. Foucault, "Governmentality", In Anthropology of the State: A Reader, eds. Aradhana Sharma \& Akhil Gupta. 131-143. USA: Blackwell Publishing, 1991.

[9] M. Foucault, The history of sexuality, vol. 1: The will to knowledge, London: Penguin, 2008.

[10] M. Dean, "Governmentality: Power and Rule in Modern Society", London: Sage Publishing, 1999.

[11] G. Burchell, C. Gordon, \& P. Miller, "The Foucault Effect: Studies in Governmentality". Chicago: University of Chicago Press, 1991.

[12] N. Rose, "Government, Authority and Expertise in Advanced Liberalism", Economy and Society, Vol. 22, No. 3, pp. 283-300, 1993.

[13] P. Miller, \& N. Rose, "Governing Economic Life". Economy and Society, Vol. 19, No. 1, pp. 1-31, 1990

[14] N. Rose, "Governing "advanced" liberal democracies. In: Barry, A.; Osborne,T.; Rose, N. (eds.) Foucault and political reason: liberalism, neo-liberalism and rationalities of government. 37-63. London: UCL Press, 1996.

[15] M. Foucault, Power/knowledge: Selected interviews and other writings, 1972-1977.New York: Vintage, 1980.

[16] S. Greenhalgh, The Chinese Biopolitical: Facing the twenty-first Century. New Genetics and Society, Vol. 28, No. 3, pp. 205-222, 2009.

[17] P. Rabinow, \& N. Rose, "Biopower Today". Biosocieties. Vol 1, No 1. 195-217, 2006.

[18] S. Legg, "Foucault's Population Geographies: Classifications, Biopolitics and Governmentl Spaces”. Population, Spaces and Place. Vol 11 No 3, pp. 137-156, 2005. 
[19] Bappenas, REPELITA I, BAB XI Kesehatan dan Keluarga Berentjana, Bappenas.go.id, 1970 (Online), Available: https://www.bappenas.go.id/id/data-dan-informasi-utama/dokumenperencanaan-dan-pelaksanaan/repelita-iii---buku-i/ [Accessed January 12, 2020]

[20] D. Isnaini, "Perkembangan Program Keluarga Berencana (Kb) Di Kotamadya Yogyakarta Tahun 1970-1998”, Jurnal Prodi Ilmu Sejarah, Vol. 3, No. 3, pp. 389-403, 2018.

[21] A. Sulistyawati, Pelayanan Keluarga Berencana, Jakarta: Salemba Medika, 2013.

[22] Ditjenpkp2trans, transmigrasi masa doeloe kini dan harapan kedepan. Jakarta: ditjenpkp2trans.Kemendesa, 2015.

[23] P. Rabinow, 'Introduction' in Rabinow, P. (ed.) “The Foucault Reader”. New York: Pantheon Book, 1984.

[24] K. Muhammad, Penerapan Norma Keluarga Kecil Bahagia dan Sejahtera dalam Era Globalisasi. Pidato di Universitas Pertanian Bogor (IPB) tahun 1993, Reprository IPB, 1993(Online), Available: https://repository.ipb.ac.id/handle/123456789/24550 [Accessed 17 January 2020] 